\title{
PERANCANGAN APLIKASI ABSENSI KARYAWAN BERDASARKAN $Q R$ CODE BERBASIS ANDROID PADA PT. MANDIRI UTAMA FINANCE
}

\author{
Bayu Surachmad, Haris Yuana, Ni’ma Kholila \\ Program Studi Teknik Informatika, Fakultas Teknologi Informasi \\ Universitas Islam Balitar, Jalan Majapahit Blitar, Indonesia \\ Bayu.dhomz96@gmail.com
}

\begin{abstract}
ABSTRAK
Saat ini dirasa tidak efisien apabila masih menggunakan finger print untuk kegiatan presensi perusahaan dengan adanya pandemi Covid-19. Selain adanya Covid-19 dan penggunaan finger print, kecurangan dalam melakukan presensi masih ditemukan pada kegiatan absensi manual dengan menggunakan buku daftar hadir karyawan. Oleh karena itu, perusahaan perlu memanfaatkan kemajuan teknologi dengan menggunakan aplikasi absensi melalui $q r$ code pada smartphone android. Tujuan dari penelitian ini yaitu merancang dan menguji aplikasi absensi karyawan berdasarkan $q r$ code berbasis android pada PT. Mandiri Utama Finance.

Metode perancangan penelitian ini berupa prototype dengan teknik pengumpulan data meliputi observasi, wawancara, dan studi pustaka. Pada penelitian ini menggunakan code generation dalam perancangan desain aplikasi berupa location based service (LBS) dengan jenis pengujian close beta testing.

Hasil penelitian ini menunjukkan bahwa aplikasi absensi karyawan yang dirancang dapat meningkatkan kinerja karyawan terhadap perusahaan. Aplikasi ini mempermudah pengolahan data absensi karyawan secara komputerisasi yang sudah tersedia dan yang sudah terdigitalisasikan dengan smartphone yang bersifat efektif dan efesien. Dari hasil pengujian beta menunjukkan bahwa aplikasi absensi karyawan memperoleh prosentase rata-rata sebesar $76 \%$. Berdasarkan rata-rata tersebut menunjukkan bahwa secara keseluruhan menu-menu yang ada dalam aplikasi absensi telah dinyatakan berfungsi dengan baik.
\end{abstract}

\section{Kata Kunci : Perancangan Aplikasi, Qr Code Berbasis Android, Absensi Karyawan}

\section{PENDAHULUAN}

Saat ini kegiatan presensi masih dirasa kurang efektif dan efisien jika dilakukan secara manual, sedangkan perkembangan zaman terus mengalami kemajuan. Hal ini dapat mengakibatkan timbulnya kesalahan, kegiatan presensi yang kurang efektif karena masih memakai kertas, terkadang lupa untuk mengisi presensi, bahkan ada yang kehilangan kertas presensi, tidak terdata pada saat pelaporan setiap bulannya, hingga menitipkan absensi kehadiran kepada sesama karyawan. Tindakan tersebut dapat menjadi indikator adanya kecerobohan dan kecurangan karyawan sehingga dapat mendorong timbulnya manipulasi data absen.

Maka dari itu, pada masa modern seperti saat sekarang ini banyak digunakan oleh masyarakat, bahkan dapat dimanfaatkan untuk sistem presensi di perusahaan seperti pada tempat penelitian berlangsung. Berdasarkan proses observasi dan wawancara bersama Human Resources Development (HRD) dari PT. Mandiri Utama Finance yaitu Bapak Susilo Wahyu Utomo penulis membahas masalah terkait kegiatan absensi. Kegiatan absensi di PT. Mandiri Utama Finance masih menggunakan alat yaitu finger print. Pada saat ini dirasa tidak efisien apabila masih menggunakan finger print untuk kegiatan presensi dengan adanya pandemi Covid-19. Kegiatan presensi menggunakan finger print yang ada saat ini masih terbatas dengan pengguna yang sangat banyak. Ketika alat absensi yang digunakan tidak sebanding dengan banyaknya pengguna, tidak menutup kemungkinan adanya virus yang dapat menyebar. Selain adanya Covid-19 dan penggunaan finger print, di PT. Mandiri Utama Finance juga masih ditemukan adanya kecurangan antar karyawan saat melakukan absensi manual dengan menggunakan buku daftar hadir karyawan yang ada di tempat Satpam. Oleh karena itu, perusahaan perlu memanfaatkan kemajuan teknologi dengan menggunakan aplikasi absensi melalui qr code pada smartphone android milik masing-masing karyawan.

Kegiatan presensi pada karyawan ini dapat dilakukan apabila karyawan telah melakukan scan $q r$ code terlebih dahulu di mana scan tersebut dibuat dengan menggunakan ZXing dalam perancangan program absensi, sedangkan untuk $q r$ code dibuat dengan menggunakan library endroid. Library di sini dapat dipahami sebagai kumpulan kode yang digunakan untuk mempermudah dalam merancang sebuah aplikasi.

Selain itu, fitur dari aplikasi ini juga dilengkapi dengan adanya penggunaan location based service (LBS). Penggunaan LBS ini untuk menghitung latitude dan longitude guna mendapatkan hasil jarak dalam satuan meter ketika karyawan melakukan absensi pada aplikasi yang dirancang. Jadi, dengan dirancangnya aplikasi absensi karyawan berbasis android ini dapat memudahkan karyawan dalam melakukan absensi, sehingga kegiatan presensi dapat berjalan dengan lebih optimal, efektif dan efisien. 


\section{TINJAUAN PUSTAKA}

\subsection{Kajian Penelitian}

Pada penelitian yang dilakukan oleh Dennis dan Nia Ekawati (2021) dengan judul "Perancangan Aplikasi Absensi Karyawan dengan Menggunakan Kode $Q R$ Berbasis Android", diperoleh informasi bahwa penggunaan aplikasi mampu membantu admin maupun pemilik took untuk melakukan absensi karyawan. Dilakukan engan menggunakan $Q R$ code yang terdapat smartphone. Selain juga dapat merancang maupun mengaplikasikan aplikasi absensi karyawan secara realtime pada masing-masing handphone [1].

Ada juga penelitian yang dilakukan oleh Sikumbang, M. A. R, dkk (2020) dengan judul "Sistem Informasi Absensi Pegawai Menggunakan Metode RAD dan Metode LBS Pada Koordinat Absensi", diperoleh informasi mengenai pengaplikasian metode location based service.

Location based service ialah sebuah metode yang berfungsi untuk mengakses layanan informasi geografis oleh pengguna perangkat (handphone). Location based service bermanfaat ntuk dapat melihat lokasi pengguna handphone. Penelitian ini dapat menjadi sarana bagi perusahaan dan pegawai untuk melakukan kegiatan absensi dengan mudah dan efisien [2].

\subsection{Aplikasi}

Dapat diartikan aplikasi merupakan sebuah program yang dapat digunakan untuk melakukan perintah dari pengguna aplikasi untuk mendapatkan hasil yang lebih akurat sesuai dengan tujuan dari pembuatan sebuah aplikasi [3].

\subsection{Absensi}

Absensi adalah tidak hadir, namun absensi juga bisa dipahami sebagai kehadiran maupun ketidakhadiran dari suatu objek dalam hal ini ialah orang. Orang tersebut merupakan anggota sebuah organisasi/perusahaan yang mewajibkan melakukan pemberitahuan terkait dengan kehadiran dan ketidakhadiran [4].

\subsection{Karyawan}

Pada Undang-Undang Nomor 13 Tahun 2003 tentang Ketenagakerjaan Pasal 1 Ayat 2 tertulis karyawan ialah setiap orang yang dapat melaksanakana pekerjaan untuk menghasilkan barang dan jasa. Untuk dapat memenuhi kebetuhan sendiri atau masyarakat di luar atau di dalam hubungan kerja [5].

\subsection{Android}

Android ialah sebuah sistem operasi yang terdapat pada handphone dengan sifatnya yang terbuka dan berbasis pada sistem operasi Linux. Android juga telah menyediakan platform terbuka untuk para pengembang agar pengguna dapat dengan mudah dalam mmbuat aplikasi mereka sendiri yang akan digunakan untuk bermacam peranti bergerak [6].

\subsection{QR Code}

Menurut Dennis dan Ekawati (2021:108), Quick Response Code atau $Q R$ Code atau Kode $Q R$ adalah simbol seperti dua dimensi yang di bangun oleh Denso Wave. Kode QR adalah anak perusahaan Toyota yang dibuat pada tahun 1994 di Jepang. $Q R$ Code ini berfungsi untuk menyampaikan berbagai informasi dan mengirim tanggapan dengan cepat. Kode $Q R$ merupakan perkembangan dari $q r$ code yang hanya dapat menyimpan informasi secara horizontal. Namun, $Q R$ Code dapat menyimpan berbagai informasi secara horizontal dan vertical. Selain itu juga mampu menampung banyak informasi.

\subsection{ZXing}

Zxing dapat diartikan sebagai open source library berbasis Java. ZXing banyak digunakan sebagai decoding $q r$ code yang juga merupakan sebuah library image processing. Pada bahasa pemrograman qr code multi format 1D/2D yang open source. Zxing memiliki fokus menggunakan built in kamera pada perangkat. Selanjutnya digunakan untuk $q r$ code foto dan membaca sandi pada perangkat tanpa melakukan komunikasi dengan server [7].

\subsection{Location Based Service (LBS)}

Menurut Sikumbang, Roni dan Syafrial (2020:60), Location Based Service (LBS) biasa dipakai sarana mengakses layanan informasi geografis. LBS digunakan dengan cara menautkan perangkat selular dengan jaringan internet untuk menentukan sebuah lokasi dimana ia berada. Penggunaan dan pemanfaatan layanan LBS ini bertujuan untuk mendapatkan posisi pengguna melalui GPS atau A-GPS. Mengacu pada 2 jenis layanan memperoleh posisi pengguna melalui koordinat longitude dan latitude.

\section{METODE PENELITIAN}

\subsection{Metode Penelitian Rancangan}

Penelitian ini memakai metode perancangan prototype. Tahapan pertama yaitu mengumpulkan data secara kualitatif, kedua membangun prototype berdasarkan data yang sudah didapat dari wawancara, ketiga pengembangan sistem, keempat evaluasi sistem dilakukan kepada karyawan PT. Mandiri Utama Finance untuk menyesuaikan kecocokan aplikasi absensi yang telah dirancang.

\subsection{Teknik Pengumpulan Data}

a. Observasi

Observasi merupakan metode/cara pengumpulan data melalui pengamatan secara langsung dan berkala pada aktivitas presensi yang dilakukan oleh karyawan yang ada di PT. Mandiri Utama Finance, serta pengamatan pada program 
pengolahan data absensi yang dijalankan secara otomatis melalui aplikasi absensi yang masih dirancang.

b. Wawancara

Wawancara merupakan kegiatan tatap muka yang dilakukan melalui adanya pertemuan 2 orang atau lebih untuk melakukan pertukaran informasi maupun ide dengan cara tanya jawab.

c. Studi Pustaka

Studi pustaka yaitu metode pencarian data dari objek perusahaan lansung, jurnal dan literatur yang lain yang memiliki hubungan dengan aplikasi yang sedang dibuat. Juga terhubung dengan dokumen yang berkaitan dengan data yang diperlukan untuk penelitian atau perancangan aplikasi absensi untuk karyawan.

\subsection{Skema Metode Perancangan}

a. Entity Relational Diagram (ERD)

Entity Relational Diagram (ERD) merupakan sebuah alat pemodelan data utama dan akan membantu melakukan organisasi data-data dalam suatu proyek ke dalam entitas-entitas dan menentukan hubungan antar entitas.

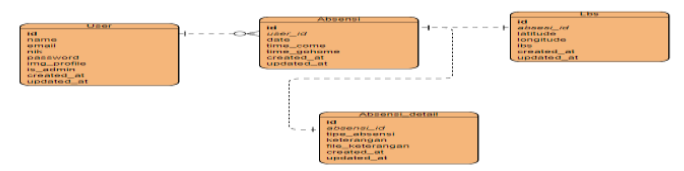

Gambar 1. Entity Relational Diagram

b. Diagram Konteks

Untuk menggambarkan perancangan proses, pengguna bisa melakukan login. Sistem ini memiliki tugas untuk mengatur dan mengelola berbagai data serta proses yang ada pada sistem. System dapat melakukan proses manipulasi pada semua data yang tersedia, seperti mengedit juga menghapus data.

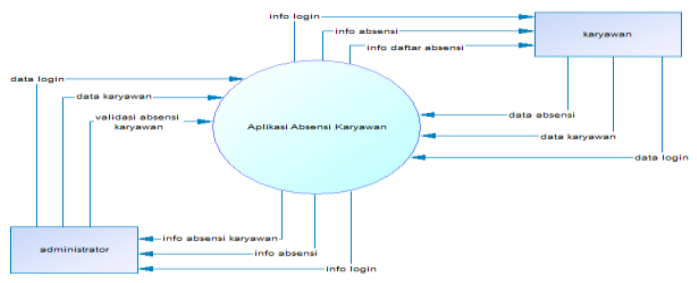

Gambar 2. Diagram Konteks

\section{c. Data Flow Diagram (DFD)}

Data Flow Diagram (DFD) Level 1 yaitu data yang menjelaskan proses yang ada di dalam sistem. Yaitu dibuat berdasarkan diagram konteks. Selanjutnya proses tersebut di bagi menjadi 4 (empat), yaitu proses login, proses absensi, validasi absensi karyawan dan daftar absensi karyawan. DFD level 1 dapat dilihat pada Gambar di bawah ini.

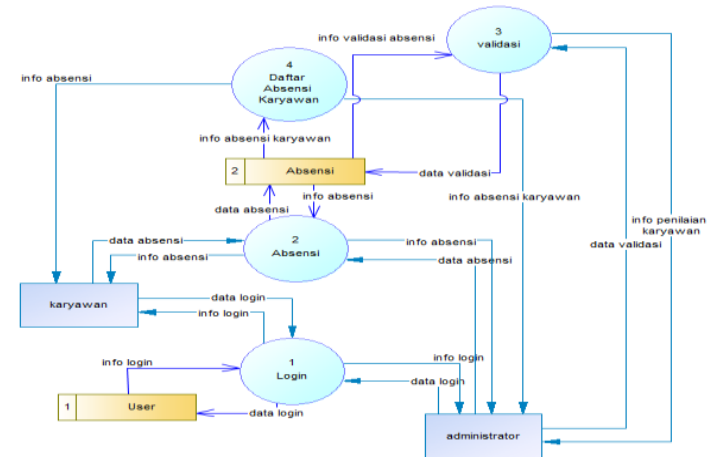

Gambar 3. Data Flow Diagram Level 1

\section{d. Flowchart}

Flowchart yang digunakan dalam perancangan aplikasi absensi karyawan dijelaskan melalui gambar berikut.

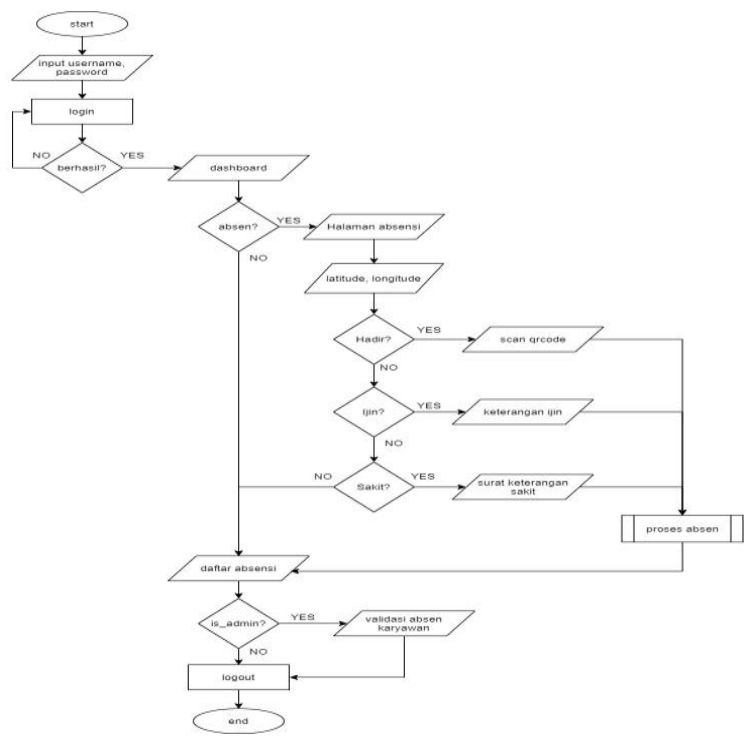

Gambar 4. Flowchart

\subsection{Model Pengembangan Sistem}

a. Analisis

Penulis melakukan analisis mengenai berbagai kebutuhan yang diperlukan oleh pengguna. Informasi tersebut meliputi data karyawan dari PT. Mandiri Utama Finance dan informasi yang berkaitan dengan sistem absensi yang akan digunakan.

b. Desain

Tahap selanjutnya ialah penulis mulai membuat desain rancangan antar muka aplikasi. Desain aplikasi dibuat dengan sederhana juga tampilan semenarik mungkin. Agar aplikasi tersebut mudah dalam pengoperasiannya oleh karyawan.

c. Code Generation

Tahap ketiga, penulis membuat kode-kode program dengan rancangan desain aplikasi yang telah dibuat dalam tahap desain. Code generation yang dipakai pada perancangan desain aplikasi ini menggunakan metode location based service (LBS). Penggunaan LBS ini dapat dijadikan 
sebagai layanan yang menunjang proses penentuan lokasi dalam aplikasi android yang akan dibuat. Metode LBS ini menggunakan nilai dari titik latitude dan longitude pada bumi untuk menentukan lokasi yang akan diinput.

d. Pengujian

Ketika aplikasi selesai dibuat, maka akan dilakukan pengujian. Pengujian dilakukan melalui sistem close beta testing. Untuk pengujian user interface akan diterapkan pada peserta penguji dari 9 (sembilan) karyawan yang ada di PT. mandiri Utama Finance dan 1 (satu) dosen Fakultas Teknologi Informasi Universitas Islam Balitar. Selanjutnya, hasil eksekusi akan diamati melalui uji data juga memeriksa fungsional dari perangkat lunak mulai dari tampilan awal hingga tombol keluar dapat dilakukan dengan pengujian fungsional dari aplikasi yang dirancang. Selain menggunakan metode pengujian beta berupa pengujian user interface dan pengujian fungsional, perlu juga dilakukan pengujian validator. Pengujian ini berupa validasi program yang akan diujikan oleh ahli media dari 2 (dua) penguji melalui karyawan PT. Mandiri Utama Finance dan ahli materi dari dosen Fakultas Teknologi Informasi Universitas Islam Balitar.

\subsection{Evaluasi Sistem}

Evaluasi sistem ini didasarkan pada hasil pengujian pada pengguna. Artinya, dalam memeriksa dan menilai suatu program diperlukan pendapat dari berbagai pihak sebagai tolok ukur guna mengetahui letak dari program yang memerlukan perbaikan. Dari hasil pengujian yang dilakukan kepada karyawan PT. Mandiri Utama Finance dan dosen terpilih yang ada di Universitas Islam Balitar dapat dijadikan sebagai acuan dalam menyesuaikan kecocokan aplikasi absensi yang telah dirancang dengan kebutuhan perusahaan dalam masa pandemi Covid-19 ini.

\section{HASIL DAN PEMBAHASAN \\ 4.1. Halaman Registrasi}

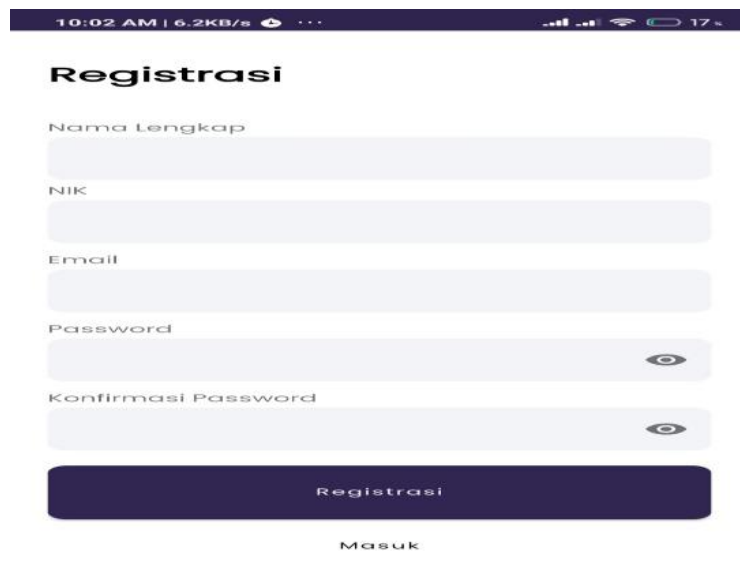

Gambar 5. Halaman Registrasi
Halaman registrasi merupakan tampilan pendaftaran di mana di dalamnya memuat proses maupun cara untuk mengisi persyaratan agar pengguna aplikasi dapat masuk pada halaman login.

\subsection{Halaman Untuk Login}

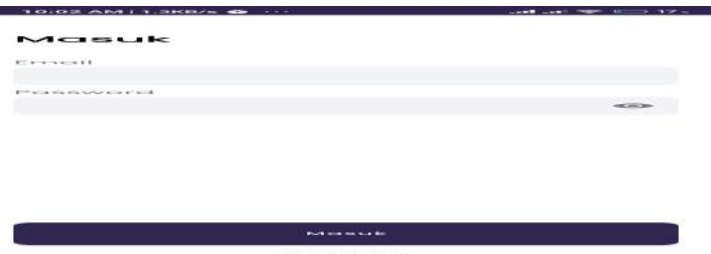

Gambar 6. Halaman Login

Halaman untuk login merupakan halaman program yang dapat dipakai karyawan di PT. Mandiri Utama Finance untuk masuk ke dalam sistem aplikasi absensi perusahaan.

\subsection{Halaman Edit Profil}

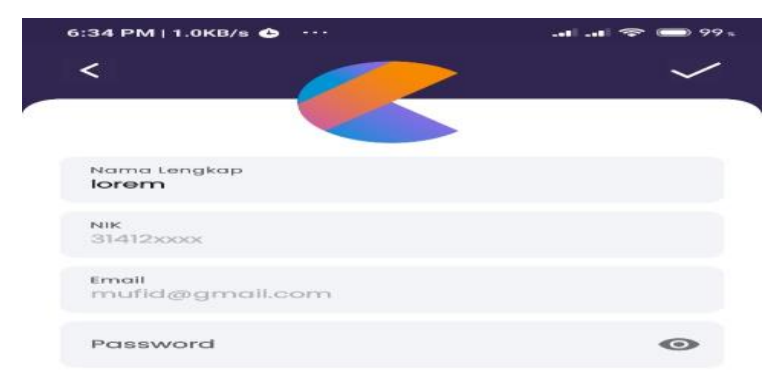

Gambar 7. Halaman Edit Profil

Halaman ini berisi beberapa keterangan yang harus diisi apabila pengguna berkeinginan untuk mengganti profil.

\subsection{Halaman Beranda}

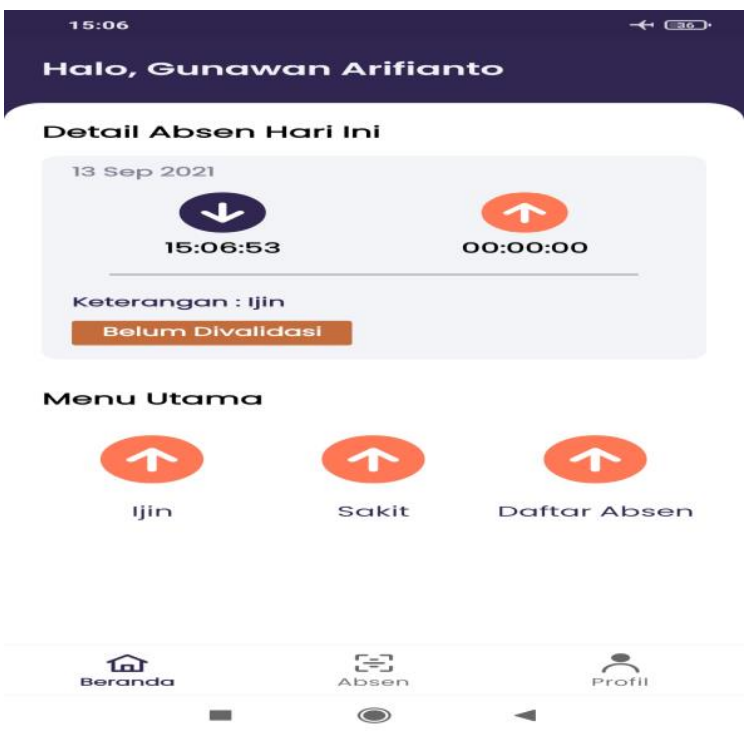

Gambar 8. Halaman Beranda 
Pada halaman ini menunjukkan detail absensi pada saat pengguna aplikasi melakukan kegiatan presensi dengan menyajikan informasi yang berkaitan dengan tanggal presensi dan waktu presensi dilakukan baik saat absen kehadiran maupun absen kepulangan karyawan yang ada di PT Mandiri Utama Finance. Selain itu, pada detail absensi juga disajikan keterangan, misalnya keterangan yang berkaitan dengan karyawan yang melakukan izin baik karena sakit maupun ada kegiatan di luar kantor. Selanjutnya, pada tampilan ini juga menunjukkan adanya menu utama yang menyajikan tentang menu perizinan, sakit, hingga daftar absen yang erat kaitannya dengan keterangan detail absen karyawan.

\subsection{Generate QR Code}

Proses generate atau pembuatan $q r$ code dilakukan ketika proses registrasi user karyawan. Pembuatan $q r$ code dilakukan di sisi server dengan menggunakan pustaka endroid- $q r$ code. Proses pertama yang dilakukan dengan menambahkan pustaka ke dalam server. Kemudian kode yang digunakan untuk pembuatan $q r$ code diletakkan pada kode registrasi user. Pada saat pembuatan $q r$ code pastikan data yang ada pada sebuah $q r$ code bersifat unique, artinya $q r$ code satu dengan yang lain memiliki data yang berbeda atau tidak sama. Pembuatan unique data bisa dilihat pada penggalan kode di bawah ini.

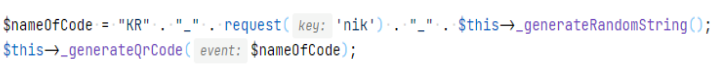

Gambar 9. Source Code Unique

Pada kode di atas setelah pembuatan unique data, selanjutnya yaitu memanggil function untuk membuat qr code, seperti kode di bawah ini.

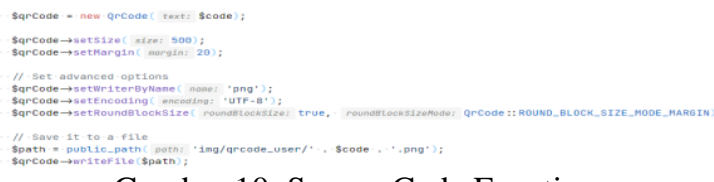

Gambar 10. Source Code Function

Pada tahapan ini dilakukan instansiasi terhadap pustaka Endroid-qr code dengan diikuti sebuah konstruktor unique data pada $q r$ code. Selanjutnya melakukan setting terhadap bentuk $q r$ code seperti ukuran qr code, margin, format extension, dan path untuk tempat penyimpanan qr code ketika berhasil dibuat. Hasil dari generate qr code ini berupa file $q r$ code yang disimpan ke dalam path, dan unique data qr code disimpan ke dalam database.

Pada Gambar 11 di atas merupakan gambar dengan pola $q r$ code yang nantinya akan dilakukan proses pemindaian (scanning) oleh pengguna aplikasi.

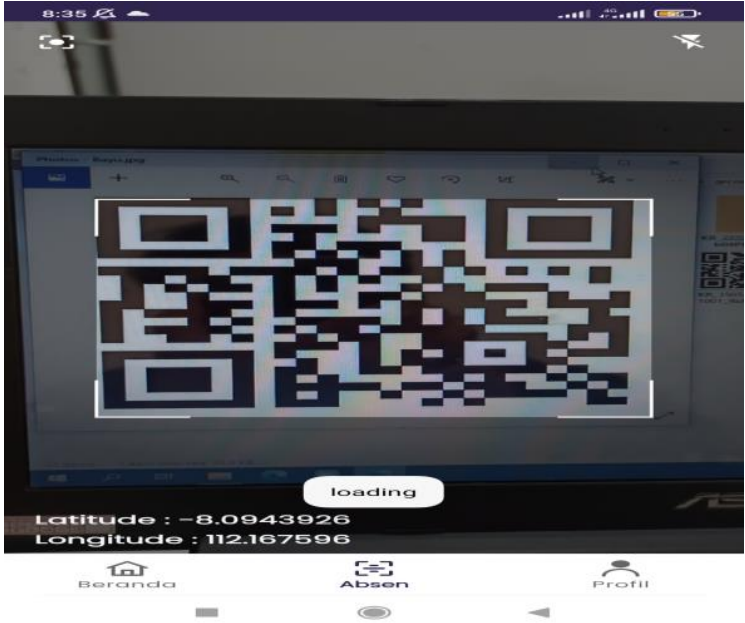

Gambar 11. Layout QR Code

\subsection{Proses Pemindaian QR Code}

Pada proses pemindaian $q r$ code, user melakukan login terlebih dahulu. Selanjutnya, pengguna menekan menu absen pada menu bottom navigation. Setelah itu, layar aplikasi akan pindah ke halaman scanning. Pengguna mengarahkan kamera pada perangkat handphone pada label qr code pada perangkat yang ingin diidentifikasi. Fungsi dari scanner pada aplikasi menggunakan pustaka Zxing. Selanjutnya, hasil scanning yang dimaksud adalah sebuah unique data karyawan. Unique data karyawan tersebut dikirimkan ke server sebagai data untuk melakukan absensi. Data kemudian dikirim kembali keperangkat android dalam bentuk JSON untuk ditampilkan hasil dari pemrosesan di server. Isi dari data JSON tersebut berupa data pengguna berhasil atau tidak dalam melakukan proses absensi.

Selanjutnya, proses dari pengiriman ke server diikuti dengan pengiriman data latitude dan longitude dari pengguna. Latitude dan longitude diambil menggunakan penggalan kode di bawah ini.

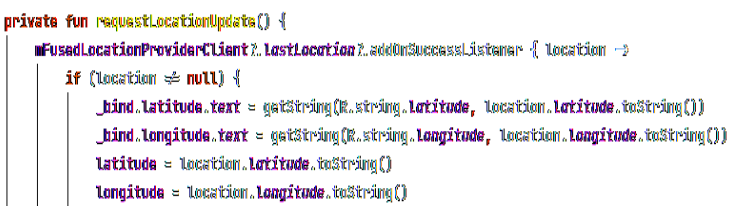

Gambar 12. Source Code Request Location Update

Latitude dan longitude yang sudah diambil menggunakan kode di atas dikirimkan ke server beserta unique data karyawan yang berasal dari hasil scanning qr code, yang selanjutnya data tersebut di proses di server.

Di dalam server data yang dikirim dari aplikasi android ditangkap. Selanjutnya dari data tersebut dilakukan proses pemindaian jarak menggunakan perhitungan LBS. Data latitude dan longitude pengguna yang dikirim dari android akan dikirim sebagai parameter ke dalam function LBS. 
Menghitung jarak menggunakan LBS memiliki 2 inputan yaitu berkaitan dengan titik lokasi pengguna, dan titik lokasi kantor. Kemudian inputan tersebut dimasukkan ke dalam kode di bawah ini.

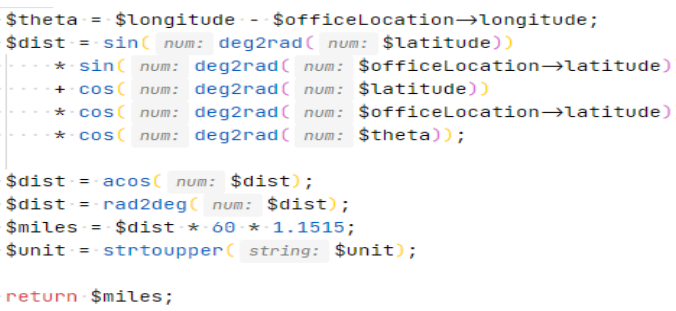

Gambar 13. Source Code Inputan LBS

Hasil dari kode di atas adalah sebuah jarak yang diukur antara titik lokasi pengguna dengan titik lokasi kantor dengan satuan meter.

\subsection{Tampilan Penerapan Metode LBS Pada Menu Sakit}
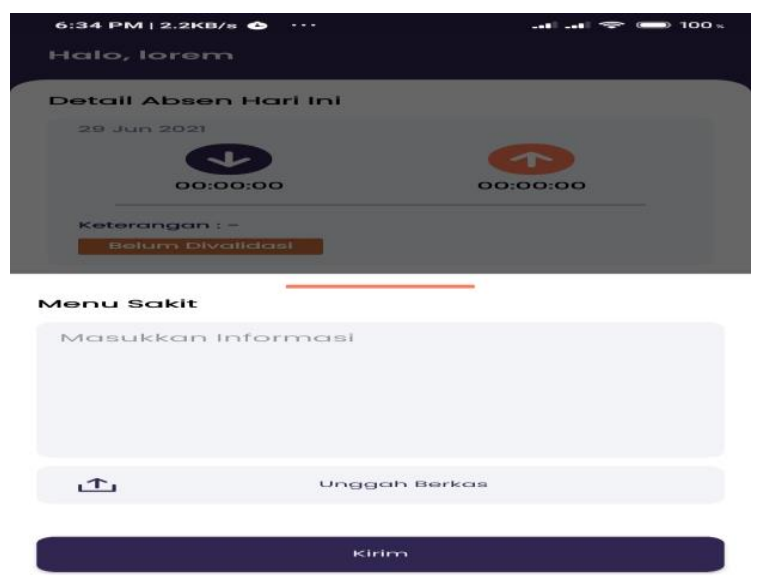

Gambar 14. Menu Sakit

Berdasarkan Gambar 14 di atas menunjukkan menu utama yang berkaitan dengan kegiatan absensi kategori sakit sebagai keterangan karyawan. Pengguna akan diarahkan untuk memasukkan informasi yang berkaitan dengan kondisi yang dialami karyawan atas sakit yang diderita. Untuk mendukung informasi atas keterangan sakit tersebut, karyawan harus mengunggah berkas yang berkaitan dengan sakit yang dideritanya. Berkas itu bisa didapatkan saat karyawan berobat dengan meminta surat dokter.

\subsection{Tampilan Penerapan Metode LBS Pada Menu Perizinan}

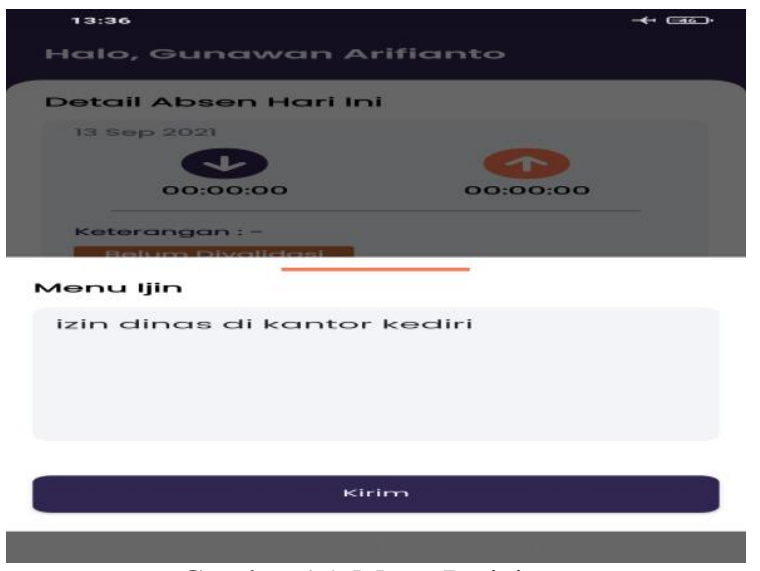

Gambar 15. Menu Perizinan

Pada menu izin ini pengguna akan diarahkan untuk memasukkan informasi yang berkaitan dengan alasan pengguna melakukan izin kerja seperti pada gambar di atas yang mengisi izin kerja dengan alasan izin dinas di Kantor Kediri.

\subsection{Halaman Daftar Absen}
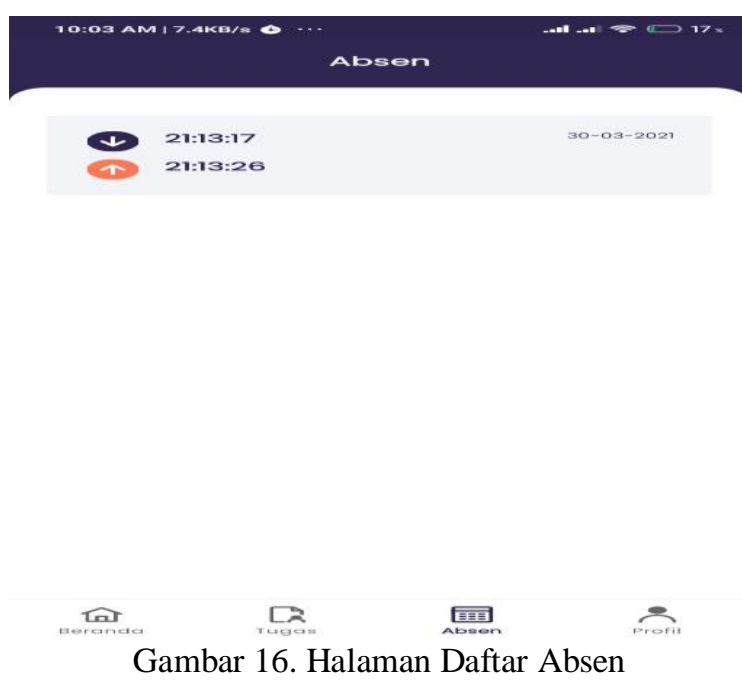

Pada tampilan ini disajikan informasi atas waktu kehadiran maupun waktu kepulangan karyawan, dan menunjukkan tanggal saat pengguna melakukan absensi. 


\subsection{Halaman Validasi Absensi (Admin)}

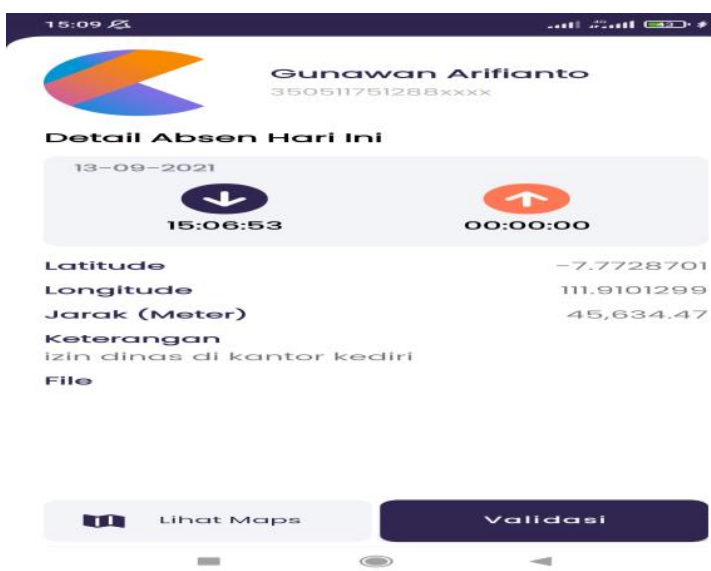

Gambar 17. Halaman Validasi Absensi oleh Admin

Tampilan ini berisi informasi yang berkenaan dengan detail absen. Detail absen yang dimaksud meliputi tanggal dilakukannya absensi dan waktu kehadiran maupun kepulangan dari setiap karyawan yang ada di PT Mandiri Utama Finance seperti yang dilakukan oleh Gunawan Arifianto. Selain itu, pada tampilan ini menunjukkan informasi yang berkaitan dengan latitude dan longtitude, jarak, keterangan saat melakukan absensi, sertas berkas apabila keterangan yang dilakukan berkaitan dengan keterangan sakit. Jarak saat Gunawan Arifianto melakukan absensi dapat diketahui sebesar 45,634.47 meter. Jarak yang sangat jauh dari kantor ini dikarenakan Gunawan Arifianto melakukan absensi dengan posisi masih berada di Kota Kediri sehingga Gunawan Arifianto mengisi menu perizinan dengan keterangan izin dinas di Kantor Kediri.

\subsection{Pengujian Program Aplikasi Absensi \\ Karyawan}

Sebelum melakukan wawancara kepada informan, terlebih dahulu penulis mempersiapkan pertanyaan-pertanyaan yang akan dijawab oleh informan sebagai pengguna aplikasi. Tabel di bawah ini menunjukkan pertanyaan yang terdapat pada pengujian beta aplikasi absensi karyawan.

Tabel 1. Pertanyaan Pengujian User Interface

\begin{tabular}{|c|l|c|c|c|}
\hline \multirow{2}{*}{ NO } & \multicolumn{1}{|c|}{ PERTANYAAN } & \multicolumn{2}{|c|}{ JAWABAN } \\
\cline { 3 - 5 } 1 & $\begin{array}{l}\text { Kesesuaian penggunaan warna dan } \\
\text { desain latar belakang pada aplikasi } \\
\text { absensi karyawan }\end{array}$ & & & KB \\
\hline 2 & $\begin{array}{l}\text { Kesesuaian warna tulisan dengan latar } \\
\text { belakang pada aplikasi absensi karyawan }\end{array}$ & & & \\
\hline 3 & $\begin{array}{l}\text { Ketepatan ukuran tulisan pada aplikasi } \\
\text { absensi karyawan }\end{array}$ & & & \\
\hline 4 & Kesesuaian ukuran tombol pada aplikasi & & & \\
\hline 5 & $\begin{array}{l}\text { Keterangan fungsi tombol dengan tujuan } \\
\text { menu yang diinginkan }\end{array}$ & & & \\
\hline 6 & Kemudahan dalam registrasi & & & \\
\hline 7 & Kemudahan dalam login & & & \\
\hline 8 & Kemudahan dalam registrasi edit profil & & & \\
\hline 9 & Kemudahan dalam memahami tampilan & & & \\
\hline
\end{tabular}

\begin{tabular}{|c|c|c|}
\hline & beranda & \\
\hline 10 & $\begin{array}{l}\text { Kemudahan dalam melakukan absensi } \\
\text { dengan scan qr code }\end{array}$ & \\
\hline 11 & $\begin{array}{l}\text { Kemudahan dalam membuat absensi } \\
\text { perizinan }\end{array}$ & \\
\hline 12 & $\begin{array}{l}\text { Kemudahan dalam membuat absen sakit } \\
\text { dengan menguplod berkas pendukung }\end{array}$ & \\
\hline 13 & $\begin{array}{l}\text { Ketetapan dan kecepatan dalam } \\
\text { memproses daftar absen dengan } \\
\text { menyertakan jarak penggunaan LBS } \\
\text { melalui latitude dan longtitude }\end{array}$ & \\
\hline 14 & $\begin{array}{l}\text { Ketepatan dan kecepatan dalam } \\
\text { memvalidasi absensi }\end{array}$ & \\
\hline 15 & $\begin{array}{l}\text { Kemudahan dan kenyamanan dalam } \\
\text { menggunakan aplikasi secara } \\
\text { keseluruhan }\end{array}$ & \\
\hline
\end{tabular}

Sumber: Data Diolah, 2021.

Dari pengujian aplikasi user interface di atas, maka perlu melakukan perhitungan guna mengetahui bobot prosentase dari masing-masing pertanyaan. Sebelum menghitung prosentase, perlu dilakukan penghitungan pada tingkat kepuasan berdasarkan skala yang ada. Berikut ini tingkat kepuasan berdasarkan skala yang ada, yaitu:

Tabel 2. Tingkat Kepuasan Pengujian

\begin{tabular}{|c|c|}
\hline TINGKAT KEPUASAN & SKALA \\
\hline Sangat Baik (SB) & 4 \\
\hline Baik (B) & 3 \\
\hline Kurang Baik (KB) & 2 \\
\hline Tidak Baik (TB) & 1 \\
\hline
\end{tabular}

Sumber: Data Diolah, 2021.

Berdasarkan tingkat kepuasan di atas, dapat dilakukan perhitungan dengan rumus:

$X=\sum(\mathrm{N} X I)$

\section{Keterangan:}

$X=$ Jumlah dari hasil perkalian nilai setiap jawaban dengan informan

$N=$ Nilai dari setiap jawaban

I = Jumlah informan

Setelah melakukan perhitungan atas tingkat kepuasan pengguna, diperlukan penghitungan skor ideal dalam perhitungan. Skor ideal ini dapat dicari dengan menggunakan rumus sebagai berikut.

Skor Ideal = Nilai Linkert Tertinggi $x$ Jumlah Informan

Dari rumus tersebut, didapatkan skor ideal dari data di atas sebesar:

Skor Ideal = Nilai Linkert Tertinggi $x$ Jumlah

Informan

Skor Ideal $\quad=4 \times 10$

Skor Ideal $\quad=40$

Langkah terakhir setelah mengetahui tingkat kepuasan berdasarkan skala dan skor ideal dari data, maka dapat diperoleh perhitungan prosentase dengan rumus:

$$
Y=\frac{X}{\text { Skor Ideal }} \times 100 \%
$$




\section{Keterangan:}

\section{$Y \quad=$ Nilai Prosentase yang dicari}

Setelah melalui beberapa perhitungan dari 15 pertanyaan dengan 10 informan diperoleh hasil prosentase untuk setiap pertanyaan seperti ditunjukkan padagambar berikut.

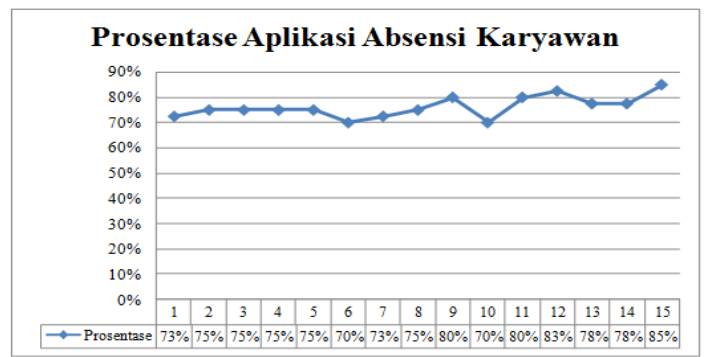

Gambar 18. Grafik Prosentase Pengujian User Interface

Apabila dilihat secara keseluruhan, prosentase pengujian user interface terendah ada pada pertanyaan ke enam dan ke sepuluh dengan prosentase $70 \%$. Pertanyaan itu berkaitan dengan kemudahan dalam melakukan registrasi dan kemudahan dalam melakukan absensi dengan scan $q r$ code. Sedangkan, nilai prosentase tertinggi ada pada pertanyaan kelima belas mengenai kemudahan dan kenyamanan dalam menggunakan aplikasi secara keseluruhan dengan prosentase sebesar $85 \%$. Dari hasil pengujian beta ini menunjukkan bahwa aplikasi absensi karyawan memperoleh prosentase rata-rata sebesar $76 \%$.

Selain dilakukan pengujian user interface, ada juga pengujian fungsional. Pengujian ini dilakukan dengan cara memeriksa apakah fitur yang disediakan pada aplikasi telah berjalan. Pengujian ini juga melibatkan karyawan pada PT. Mandiri Utama Finance Kota Blitar.

Berikut ini pertanyaan atas pengujian fungsional dalam menggunakan pengujian beta, yaitu:

Tabel 3. Pertanyaan Pengujian Fungsional

\begin{tabular}{|c|c|c|c|c|c|}
\hline \multirow{2}{*}{ NO } & \multirow{2}{*}{ PERTANYAAN } & \multicolumn{4}{|c|}{ JAWABAN } \\
\hline & & TB & KB & B & SB \\
\hline 1 & $\begin{array}{l}\text { Proses registrasi berjalan sesuai } \\
\text { dengan role yang ditetapkan sistem }\end{array}$ & & & & \\
\hline 2 & $\begin{array}{l}\text { Pada halaman registrasi, tombol } \\
\text { registrasi telah berjalan tanpa error }\end{array}$ & & & & \\
\hline 3 & $\begin{array}{l}\text { Proses login berjalan sesuai } \\
\text { dengan role yang ditetapkan sistem }\end{array}$ & & & & \\
\hline 4 & $\begin{array}{l}\text { Pada halaman login, tombol masuk } \\
\text { telah berjalan tanpa error }\end{array}$ & & & & \\
\hline 5 & $\begin{array}{l}\text { Proses edit profil berjalan sesuai } \\
\text { dengan role yang ditetapkan sistem }\end{array}$ & & & & \\
\hline 6 & $\begin{array}{l}\text { Pada halaman edit profil, menu } \\
\text { dalam mengedit yang meliputi } \\
\text { pengisian nama lengkap, nomor } \\
\text { induk kependudukan (NIK), email } \\
\text { dan password telah berjalan tanpa } \\
\text { error }\end{array}$ & & & & \\
\hline 7 & $\begin{array}{l}\text { Pada halaman beranda yang berisi } \\
\text { detail absensi yang meliputi } \\
\text { tanggal, serta waktu absen masuk } \\
\text { dan keluar telah sesuai dengan role } \\
\text { yang ditetapkan sistem, serta menu }\end{array}$ & & & & \\
\hline
\end{tabular}

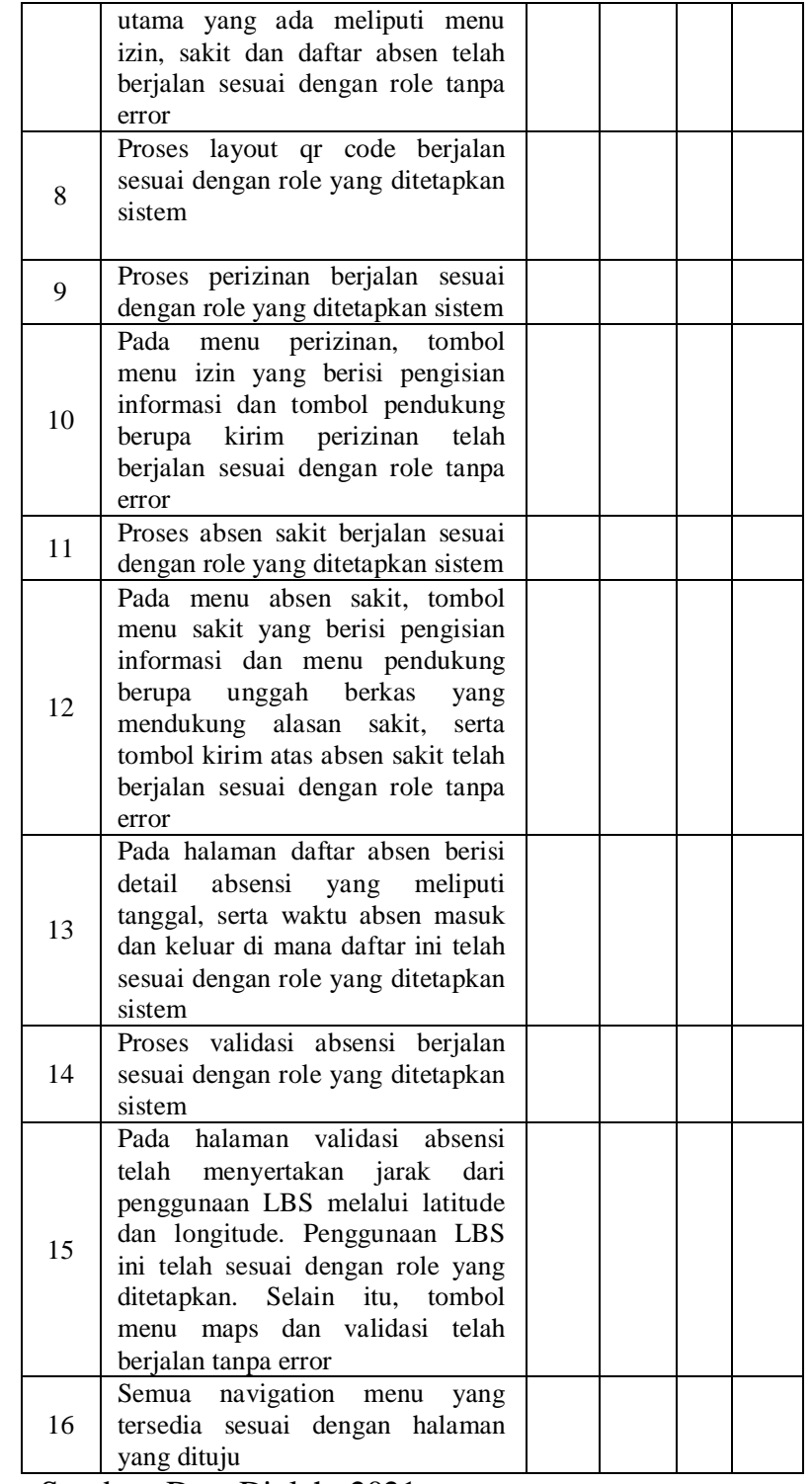

Sumber: Data Diolah, 2021.

Setelah melalui beberapa perhitungan dari 16 pertanyaan dengan 10 informan diperoleh hasil prosentase untuk setiap pertanyaan seperti gambar ini.

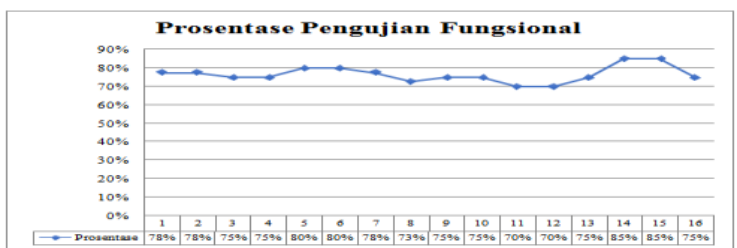

Gambar 19. Grafik Prosentase Pengujian Fungsional

Berdasarkan Gambar 19 di atas menunjukkan grafik prosentase dari hasil pengujian fungsional pada aplikasi absensi karyawan. Pada grafik tersebut dapat dilihat bahwa prosentase yang berupa pecahan dibulatkan seperti pada pertanyaan nomor 1, 2, 7, dan 8. Dari hasil pengujian fungsional ini menunjukkan 
bahwa aplikasi absensi karyawan memperoleh prosentase rata-rata sebesar $77 \%$.

Selain dilakukan pengujian user interface dan pengujian fungsional, ada juga pengujian validator. Pengujian validator dilakukan untuk menguji apakah aplikasi sudah sesuai dengan metode yang dipilih. Pihak penguji terdiri dari ahli media dan ahli materi. Tim penguji pada pengujian validator, meliputi:

Tabel 4. Pihak Penguji Validator

\begin{tabular}{|c|l|l|l|}
\hline NO & Nama Penguji & Sebagai & Jabatan \\
\hline 1 & $\begin{array}{l}\text { Susilo Wahyu } \\
\text { Utomo }\end{array}$ & $\begin{array}{l}\text { Ahli } \\
\text { Media }\end{array}$ & $\begin{array}{l}\text { Human Resources } \\
\text { Development }\end{array}$ \\
\hline 2 & $\begin{array}{l}\text { Gunawan } \\
\text { Arifianto }\end{array}$ & $\begin{array}{l}\text { Ahli } \\
\text { Media }\end{array}$ & Credit Analiyst \\
\hline \multirow{3}{*}{3} & $\begin{array}{l}\text { Sri Lestanti, } \\
\text { S.Kom.,M.T }\end{array}$ & $\begin{array}{l}\text { Ahli } \\
\text { Materi }\end{array}$ & $\begin{array}{l}\text { Dosen Fakultas } \\
\text { Teknologi Informasi } \\
\text { Universitas Islam } \\
\text { Balitar }\end{array}$ \\
\hline
\end{tabular}

Sumber: Data Diolah, 2021.

Setelah menentukan pihak penguji validator baik sebagai ahli materi dan media dapat dilanjutkan dengan penyusunan pertanyaan terkait pengujian validator. Berikut ini pertanyaan atas pengujian validator dalam menggunakan pengujian beta, yaitu:

Tabel 5. Pertanyaan Pengujian Validator

\begin{tabular}{|c|c|c|c|c|c|}
\hline \multirow{2}{*}{ NO } & \multirow{2}{*}{ PERTANYAAN } & \multicolumn{4}{|c|}{ JAWABAN } \\
\hline & & TB & KB & B & SB \\
\hline 1 & $\begin{array}{l}\text { Pengumpulan data yang } \\
\text { didapatkan sesuai dengan metode } \\
\text { perancangan prototype }\end{array}$ & & & & \\
\hline 2 & $\begin{array}{l}\text { Skema metode perancangan yang } \\
\text { meliputi ERD, diagram konteks, } \\
\text { DFD, dan flowchart sesuai dengan } \\
\text { metode perancangan prototype }\end{array}$ & & & & \\
\hline 3 & $\begin{array}{l}\text { Model pengembangan sistem yang } \\
\text { meliputi analisis, desain, code } \\
\text { generation, dan pengujian sesuai } \\
\text { dengan metode perancangan } \\
\text { prototype }\end{array}$ & & & & \\
\hline 4 & $\begin{array}{l}\text { Code generation yang digunakan } \\
\text { berupa location based service } \\
\text { (LBS) dengan menggunakan nilai } \\
\text { dari titik latitude dan longitude } \\
\text { sesuai untuk mengetahui jarak dari } \\
\text { suatu lokasi }\end{array}$ & & & & \\
\hline 5 & $\begin{array}{l}\text { Pengujian dilakukan dengan } \\
\text { menggunakan close beta testing } \\
\text { yang sesuai dalam menemukan dan } \\
\text { mengidentifikasi } \\
\text { mungkin masalah pada sistem } \\
\text { aplikasi }\end{array}$ & & & & \\
\hline 6 & $\begin{array}{l}\text { Hasil desain antarmuka sesuai } \\
\text { dengan yang ditetapka }\end{array}$ & & & & \\
\hline 7 & $\begin{array}{l}\text { Semua tahap yang dilakukan } \\
\text { sesuai dengan metode perancangan } \\
\text { prototype }\end{array}$ & & & & \\
\hline
\end{tabular}

Sumber: Data Diolah, 2021.

Setelah melalui beberapa perhitungan dari 7 (tujuh) pertanyaan dengan 3 (tiga) penguji validator diperoleh hasil prosentase untuk setiap pertanyaan dijelaskan sebagai berikut.

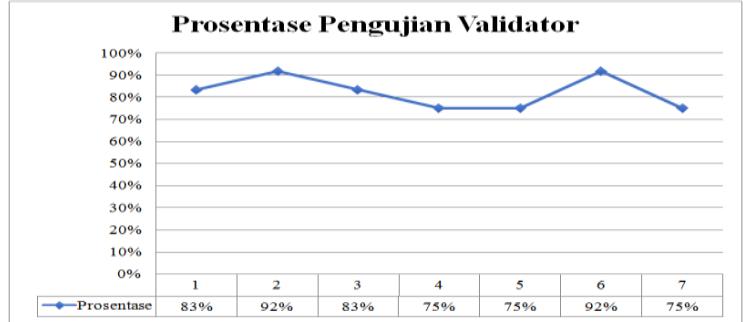

Gambar 20. Grafik Prosentase Pengujian Validator

Pada grafik di atas dapat dilihat bahwa prosentase yang berupa pecahan dibulatkan seperti pada pertanyaan nomor 1, 2, 3, dan 6. Dari hasil pengujian validator ini menunjukkan bahwa aplikasi absensi karyawan memperoleh prosentase rata-rata sebesar $82 \%$.

Berdasarkan hasil pengujian beta di atas mulai dari pengujian user interface, pengujian fungsional dan pengujian validator, dapat ditarik kesimpulan bahwa aplikasi absensi karyawan di PT Mandiri Utama Finance. Pengujian dilihat pada gambar berikut.

Tabel 6. Hasil Pengujian Beta Pada Aplikasi Absensi Karyawan

\begin{tabular}{|c|l|c|c|}
\hline No & \multicolumn{1}{|c|}{ Fungsional } & Pengguna & $\begin{array}{c}\text { Hasil } \\
\text { Pengujian }\end{array}$ \\
\hline 1 & Registration Page & Admin, karyawan & Berhasil \\
\hline 2 & Login Page & Admin, karyawan & Berhasil \\
\hline 3 & Edit Profile & Page Karyawan & Berhasil \\
\hline 4 & Home Page & Admin, karyawan & Berhasil \\
\hline 5 & Attendance Page & Karyawan & Berhasil \\
\hline 6 & Attendance List Page & Karyawan & Berhasil \\
\hline 7 & $\begin{array}{l}\text { Presence Validation } \\
\text { Page (Admin) }\end{array}$ & Admin & Berhasil \\
\hline
\end{tabular}

Sumber: Data Diolah, 2021.

Berdasarkan data diatas, secara keseluruhan menu-menu yang ada dalam aplikasi telah dinyatakan berfungsi dengan baik mulai dari halaman registrasi, halaman login, halaman edit profil, halaman beranda, halaman absensi, halaman daftar absen dan halaman validasi absensi oleh admin dapat dikatakan berhasil.

\section{KESIMPULAN DAN SARAN}

\subsection{Kesimpulan}

Melalui penelitian yang dilakukan, dapat disimpulkan bahwa:

1. Aplikasi absensi karyawan pada PT. Mandiri Utama Finance dirancang dengan menggunakan model qr code melalui pemanfaatan smartphone android. Proses perancangan scan dibuat dengan menggunakan ZXing, sedangkan untuk qr code dibuat dengan menggunakan library endroid. Metode perancangan ini berupa prototype dan menggunakan code generation dalam perancangan desain aplikasi berupa location based service (LBS). LBS ini digunakan untuk menghitung latitude dan longtitude guna mendapatkan hasil jarak dalam satuan meter ketika karyawan melakukan absensi. Dengan 
perancangan aplikasi ini menghasilkan aplikasi fungsional dari program yang meliputi registration page, login page, edit profile page, home page, attendance page, attendance list page, dan presence validation page. Adanya aplikasi ini dapat mempermudah perusahaan dalam mengolah data absensi karyawan secara komputerisasi yang sudah tersedia dan yang sudah terdigitalisasikan dengan smartphone yang bersifat efektif dan efesien.

2. Pengujian aplikasi absensi karyawan dilakukan dengan menggunakan jenis pengujian close beta testing. Pengujian beta testing ini dijalankan melalui 3 pengujian yaitu pengujian user interface, pengujian fungsional dan pengujian validator yang masing-masing pengujian menghasilkan prosentase sebesar 76\%, 77\% dan $82 \%$. Secara keseluruhan menu-menu yang ada dalam aplikasi telah dinyatakan berfungsi dengan baik dan dapat dikatakan berhasil.

\subsection{Saran}

Melalui uraian di atas, penulis memberikan beberapa saran yaitu:

1. Perlu adanya sosialisasi lanjutan untuk karyawan di PT. Mandiri Utama Finance Kota Blitar mengenai adanya aplikasi absensi karyawan berbasis android yang telah dikembangkan oleh penulis supaya manfaat dapat pula dirasakan oleh karyawan yang bekerja.

2. Selalu melakukan pembaharuan atau upgrade pada sistem aplikasi absensi karyawan supaya dapat meminimalisir terjadinya sistem yang error saat pengoperasian.

\section{DAFTAR PUSTAKA}

[1] Dennis., Ekawati, Nia. 2021. Perancangan Aplikasi Absensi Karyawan Dengan Menggunakan Kode $Q R$ Berbasis Android. Jurnal Comasie, Vol.04 No.02, 2021.

[2] Sikumbang, Mohammad Arya., Roni Habibi., Syafrial Fachri Pane. 2020. Sistem Informasi Absensi Pegawai Menggunakan Metode RAD dan Metode LBS Pada Koordinat Absensi. Jurnal Media Informatika Budidarma, Volume 4, Nomor 1, Januari 2020.

[3] Asbianto., Nasution, Helfi., dan Irwansyah, Muhammad Azhar. 2020. Rancang Bangun Aplikasi Pengolahan Data Perusahaan Mining Consultan CV. Mitra Mineral. Jurnal Sistem dan Teknologi Informasi, Vol. 8, No. 2, April 2020.

[4] Husain, Al., Abdul Haqy Aji Prastian., Andre Ramadhan. 2017. Perancangan Sistem Absensi Online Menggunakan Android Guna Mempercepat Proses Kehadiran Karyawan Pada PT. Sintech Berkah Abadi. Technomedia Journal (TMJ), Vol. 1 No.2 Edisi Februari 2017.

[5] Chandra, Agnes Melissa. 2018. Sistem Absensi Dinas Kerja Karyawan Dengan Mobile Positioning Berbasis Android Menggunakan Metode Statik Pada PT. IPRO Solusi Canggih. Skripsi. Fakultas Sains dan Teknologi, Universitas Buddhi Dharma, Tangerang.

[6] Safaat H, Nazruddin. 2012. Pemrograman Aplikasi Mobile Smartphone dan Tablet PC berbasis Android. Bandung: Informatika Bandung.

[7] N. Bhardwaj, R. Kumar, R. Verma, A. Jindal, and A. P. Bhondekar. 2016. Decoding Algorithm for Color QR Code: A Mobile Scanner Application. International Conference on Recent Trends in Information Technology, ICRTIT, 2016. 